\title{
SUSTAINABLE FOOD: AN INNOVATIVE EDUCATIONAL APPROACH IN SECONDARY SCHOOLS BASED ON THE ASSESSMENT FOR LEARNING METHOD
}

\author{
Ilaria Zandonella Necca ${ }^{1}$, Marta Bellio ${ }^{2}$, Francesca Corrà ${ }^{3}$, Marco Bonato ${ }^{4}$, Sophia \\ Schumann ${ }^{5}$, Paola Irato ${ }^{6}$, Gianni Tamino ${ }^{7}$, Gianfranco Santovito ${ }^{8 *}$ \\ ${ }^{1} \mathrm{Dr}$, University of Padova, Italy, ilary110zando@gmail.com \\ ${ }^{2}$ Dr, University of Padova, Italy, marta.bellio@unipd.it \\ ${ }^{3}$ Dr, University of Padova, Italy, francesca.corra@unipd.it \\ ${ }^{4}$ Dr., University of Padova, Italy, marco.bonato@unipd.it \\ ${ }^{5} \mathrm{Dr}$, University of Padova, Italy, sphia.schumann@studenti.unipd.it \\ ${ }^{6}$ Dr, University of Padova, Italy, paola.irato@unipd.it \\ ${ }^{7}$ Dr, University of Padova, Italy, gianni.tamino@unipd.it \\ ${ }^{8} \mathrm{Dr}$, University of Padova, Italy, gianfranco.santovito@unipd.it \\ ${ }^{*}$ Corresponding Author
}

\begin{abstract}
In 2005 the United Nations promoted the "decade of education for sustainable development" (2005-2014) and the UNESCO Italian Committee instituted the annual "week of education for sustainable development" to raise awareness about the necessity of a fairer and more respectful future for both human beings and environment. Nevertheless, the Italian Guidelines for the Curriculum in Secondary School - Key Stage 3 (2012 Edition) do not include the topic "sustainable food".

Whereas, as proved by the scientific research, human activities concerning food, its production, its transportation, its consumption, and waste discharge are one of the most important causes of environmental pollution. Therefore, it is important to raise awareness and to understand which teaching methods might be the most effective for increasing debate, interest, and willingness in order to promote environmental safety. It is fundamental to build an ecological conscience, especially in tomorrow's citizens: today's children.

The purpose of this study is to verify the opportunity to introduce this topic to the students, by transmitting knowledge through the Assessment for Learning method, innovative in Italy, and by comparing it with other methods, already commonly used. This method allows students to be protagonists of their own learning; it leads them to self-assessment and to autonomous reflection; it motivates them by creating curiosity, interest, and willingness to learn, in order to achieve more efficiency in learning and more probabilities of lifelong knowledge.
\end{abstract}

Before starting this experiment on didactics, a survey was done. A few mathematics and science teachers from different secondary schools (KS3) were interviewed about the didactic of this "subject" and on the methodologies generally used in teaching. The results confirmed that in secondary schools (KS3) this topic is not debated and that, overall, the most used methodologies are lectures and school trips.

Therefore, the didactic experiment with the Assessment for Learning went on and the results were positive. Indeed, not only the students who learnt through Assessment for Learning achieved better marks than the other students who learnt about the same topic by lectures and active techniques, but they were also more interested and motivated and, even more important, not one single student failed the final test (because of the responsible group work carried out during the lessons). Furthermore, during the lessons the students spontaneously gave their contribution with practical proposals, aimed at minimizing the environmental impact problem.

In conclusion, this study, conceived as a first test for the applicability of the Assessment for Learning method in Italian schools, shows at least the importance of organizing, in future, a didactic project based on this new 
methodology in science teaching, in order to consider, in perspective, a wider application field.

Keywords: Assessment for learning, sustainable development, sustainable food, teaching methods.

\section{INTRODUCTION}

"We do not inherit the earth from our ancestors; we borrow it from our children". These few words from a famous proverb express the right attitude we should have toward the ecological issue of our planet. It is not difficult to see how disruptive human behavior can be, particularly in the most technologically advanced cultures. It leads to exploitation of natural resources and to the release of polluting substances and massive amounts of wastes, all in the name of the consumptions of goods that are not essential.

Nowadays not only is it important to talk about sustainable food but it is fundamental.

The world population is constantly growing, and we are currently consuming the natural resources of 1.3 planets (we are consuming the reserves because we are mainly using non-renewable resources) and the situation is destined to get worse because, if we keep this pace, by 2030 we will need the resources of two planets (Pignatti and Trezza, 2000).

If it is true that a non-environmentally friendly choice of food can significantly contribute to create (Food and Agriculture Organization of the United Nations, 2006, 2010):

- Air pollution (greenhouse gases emissions due mainly to livestock and transport);

- Water pollution particularly with nitrogen and phosphorus (with consequent eutrophication);

- Bioaccumulation of pesticides and heavy metals in food webs' components;

- Biodiversity loss;

- Waste of resources such as water and energy;

- excessive production of packaging and therefore of waste, with all the connected problems (waste of resources for their production and disposal; greenhouse gases emission due to packaging production, transportation and disposal; solid waste pollution if they are abandoned in nature or if they are not properly disposed of);

- Unfair distribution of food resources;

- Deforestation and soil depletion;

It is also true that with sustainable food all this can be avoided (Rifkin, 2011).

It is therefore of the greatest importance to raise awareness and talk about the topic, most of all in schools.

As one of the greatest experts of digital communication, Nicholas Negroponte says: "Each and every global issue has a solution which comes from education and, in most cases, the solution is education itself". School is the place where an environmental education can be instilled, but it is necessary to do so in a more effective way as compared to the standard teaching methods. We need a method which can create enthusiasm, interest, diligence, cooperation, inclination for group work so that no one is left behind, building the ideal premises for a spontaneous and permanent assimilation of the subject in order to reach the greatest efficiency and the best results.

These characteristics seem to be present in the "Assessment for Learning" method, recently in use in other countries' schools (especially in England), but almost completely unknown in Italy as in many other countries. From here therefore the idea of verifying its validity in Italian schools, even though through a few limited experiments based on the specific topic of sustainable food.

\section{EXPERIMENTAL PHASE}

\subsection{Fields of Intervention}

The activities have been carried out in two Secondary Schools (Key Stage 3 - KS3): "Tito Livio", located in Teolo (PD) and "Cesarotti", located in Selvazzano (PD); each of them is part of an "Istituto Comprensivo" (Junior-Middle School).

In the first school, located in a rural zone, some pupils have their own little vegetable garden at home and 
most of the pupils are used to buy fruit and vegetables from local farmers.

\subsection{Experimental Plan}

The class III C of the Secondary School (KS3) "Tito Livio" (22 pupils) has been randomly chosen and used as control group, where the sustainable food topic was taught through a classic didactic (lectures).

In the class III A (21 pupils) of the same school, the topic has been taught through active learning.

The Assessment for Learning methodology (AfL) has been utilized with two different classes: in the class III B (20 pupils) of the school "Tito Livio" and in II B (23 pupils) of the school "Cesarotti". The choice of two classes with pupils of different age and formative experience has allowed us to compare two different targets.

\subsection{Planning the Learning Activities}

The lesson has been divided into four parts:

First part: food and health (macronutrients, micronutrients and the food pyramid).

Second part: the three sustainable food indicators, the environmental pyramid, the transportation problem and out of season food.

Third part: packaging and its most common materials. Recycling.

Fourth part: behavior to follow for sustainable living.

At the end of the lesson a test has been submitted to the pupils and later assessed to test the effectiveness of the didactic. The marks have been assigned according to the underlying score:

- For closed-ended questions 1 point per each correct answer and 0 points per each incorrect answer;

- For the first open-ended question from 0 to 2 points, 0.5 points per each listed material;

- For the second open-ended question from 0 to 3 points, 1 point per each listed "rule".

In the first school, located in a rural zone, some pupils have their own little vegetable garden at home and most of the pupils are used to buy fruit and vegetables from local farmers.

\section{METHODOLOGY}

Different methodologies, reported below, have been experimented with the aim of verifying the potentialities of the Assessment for Learning in particular.

\subsection{Lecture}

The lecture (classical method) has been utilized in all the experimental groups (classes) to introduce the topic. In the control group the classical method was used during the totality of the time dedicated to the didactic activity.

PowerPoint presentations have been utilized in all groups.

\subsection{Assessment for Learning}

This method (Gadsby, 2012), utilized in two classes (III B and II B), included active learning techniques such as discussion and brainstorming in small groups or with the entire class-group. After having detected prior knowledge of the subject, the learning objectives (and the steps which will be utilized to meet them) are shared with the class-group. An important part of the lesson is the clarification of: 1) the success criteria of the learning activity (the measures to utilize and what is considered the key knowledge to remember in order to reach an in-depth learning) and 2) the kind of feedback that the teacher will give on the carried out exercises (i. e. what feedback is, what is its use is and how feedback should be given).

The teacher's feedback is given first of all underlining two or three positive aspects and only a negative one of the carried-out exercise and then explaining how to improve the negative one. All this is written with a colored pen (not red because of the emotional impact this color could have). It is important to underline that the feedback does not involve grades, because it is not a usual assessment and errors are considered important steps towards learning. Another part of the lesson can be either the self-assessment or the peerassessment.

Since the time available was not sufficient, it has not been possible to utilize the whole Assessment for Learning method (it would be impossible in one lesson), but the indispensable and/or characteristics parts of 
this method have been employed (the sharing of the learning objectives and an exercise followed by the feedback).

First of all, a few questions were asked to the students, divided in small groups, (e.g., "What is considered a sustainable activity?") to understand what they already know about the topic. A little discussion followed this moment. In the second part of the lesson students were involved in another discussion in order to decide the learning objectives. The next activity has been a jigsaw: the students, divided into four groups, had a different topic to analyze (i.e., plastic pollution, labels of products you can find at the supermarket, packaging and different materials and suggestions to minimize our environmental impact) and some questions to answer. They have then discussed the topics with the whole class. The last part of the lesson has started with an explanation on feedback (what it is and how it can be given). Students answered a question in writing and then they swapped the answer with a peer and they gave them their feedback (peer assessment).

\subsection{Active Learning Techniques}

These techniques (Tessaro, 2011; Tessaro, 2002; Ginnis, 2001) have been briefly utilized in III B and in II B (to allow the application of the Assessment for Learning) whereas they have been the base of the activities carried out in III A. The activities in this class have been based in particular on discussion, brainstorming and on group activities such as jigsaw and, in III A only, the so called "scrambled groups".

\subsection{Utilized Equipment}

The only equipment utilized for the didactic activity is the Interactive Whiteboard (IWB).

\subsection{Investigation of the Didactic of Sustainable Food in Secondary School}

Before beginning the didactic activities, it has been found appropriate to elaborate a questionnaire for the teachers taking part in the experimentation and for others not directly involved, for a total of 32 teachers. Among these, there were a few teachers attending the "Tirocinio Formativo Attivo - classe A59, Matematica e Scienze nella Scuola Secondaria di I grado, dell'Università di Padova" (TFA - Italian equivalent of PGCE), who already have experienced teaching in the Secondary School (for a total of 13 trainees).

This questionnaire was constituted of 14 questions specifically thought to have a general view on the didactic of this topic and on the utilized methodologies, in order to verify the originality of the choices made for the experimentation.

\subsection{Statistical analyses}

Values are reported as mean. Variations among experimenta groups were investigated by the one-way analysis of variance (ANOVA) and mean comparisons were performed using the Tukey's test. The level of significance was set at $p<0.05$.

\section{RESULTS}

\subsection{Investigation of the Didactics}

The $23 \%$ of trainees attending the TFA and $58 \%$ of the teachers have answered that they have never focused on the sustainable food topic and that they are not interested in doing it in the future, one of the main reasons is because the subject is not present in the textbook used in class or because the topic in not interesting.

All the teachers who have positively answered to this question say that they teach this topic dedicating 1 or 2 hours to it, also through interdisciplinary projects with Geography and Technology. $13 \%$ of these teachers has taught it in year $7,49 \%$ in year 8 and $38 \%$ in year 9 .

Regarding the trainees of the TFA, $40 \%$ has said that they teach this topic only sometimes (dedicating to it an average of 1 or 2 hours) whereas $60 \%$, even though they have never taught it, would like to teach it in the future. In both cases, the trainees all agree on teaching it in year 8.

Regarding the didactic methodologies: $75 \%$ of the teachers use lectures, whereas only $25 \%$ use also other activities such as school trips or research papers carried out by the students.

Regarding the trainees of the TFA, $80 \%$ teach (or would teach) the topic through lectures, $10 \%$ through interactive lessons and $10 \%$ through practical experiences in the school laboratory.

Even though both teachers and trainees claim to be interested in experimenting new didactic methodologies, all the interviewed say that it is better to use more rapid methods, such as lectures due to the shortage of available time. 
Regarding assessments, $75 \%$ of the teachers would verify pupils' comprehension of this topic through an individual oral test (one question) whereas $25 \%$ would use an "in itinere" assessment, monitoring a group discussion (Fig. 4).

Regarding trainees the ideas on assessments are more varied: 40\% choose group discussion, $40 \%$ individual oral tests, $10 \%$ written tests. It is interesting to notice that $10 \%$ do not verify (or would not verify) the comprehension of the topic (Fig. 4).

All the teachers and $70 \%$ of the trainees that have taught sustainable food say that pupils are very interested in the topic.

\subsection{Results of the Test in the Different Classes}

Table 1 and Figure 1 show the distribution of grades achieved by the pupils of the four examined classes in the final test.

Table 1. Grades, in percentage, achieved by the pupils of the four classes.

\begin{tabular}{|l|c|c|c|c|c|c|c|c|}
\hline & Grade 10 & Grade 9 & Grade 8 & Grade 7 & Grade 6 & Grade 5 & Grade 4 & Average \\
\hline $\begin{array}{l}\text { III C } \\
\text { Lecture }\end{array}$ & $35.4 \%$ & $22.7 \%$ & $13.6 \%$ & $4.5 \%$ & $9.0 \%$ & $4.5 \%$ & $9.0 \%$ & 8.22 \\
\hline $\begin{array}{l}\text { III A } \\
\text { Active } \\
\text { techniques }\end{array}$ & $23.8 \%$ & $47.6 \%$ & $9.5 \%$ & --- & $4.8 \%$ & $4.8 \%$ & $9.5 \%$ & 8.33 \\
\hline $\begin{array}{l}\text { III B } \\
\text { Assessment } \\
\text { for Learning }\end{array}$ & $35.0 \%$ & $35.0 \%$ & $20.0 \%$ & $10.0 \%$ & --- & --- & --- & 8.95 \\
\hline $\begin{array}{l}\text { II B } \\
\text { Assessment } \\
\text { for Learning }\end{array}$ & $45.5 \%$ & $31.8 \%$ & $4.5 \%$ & $9.0 \%$ & $9.0 \%$ & --- & --- & 8.95 \\
\hline
\end{tabular}

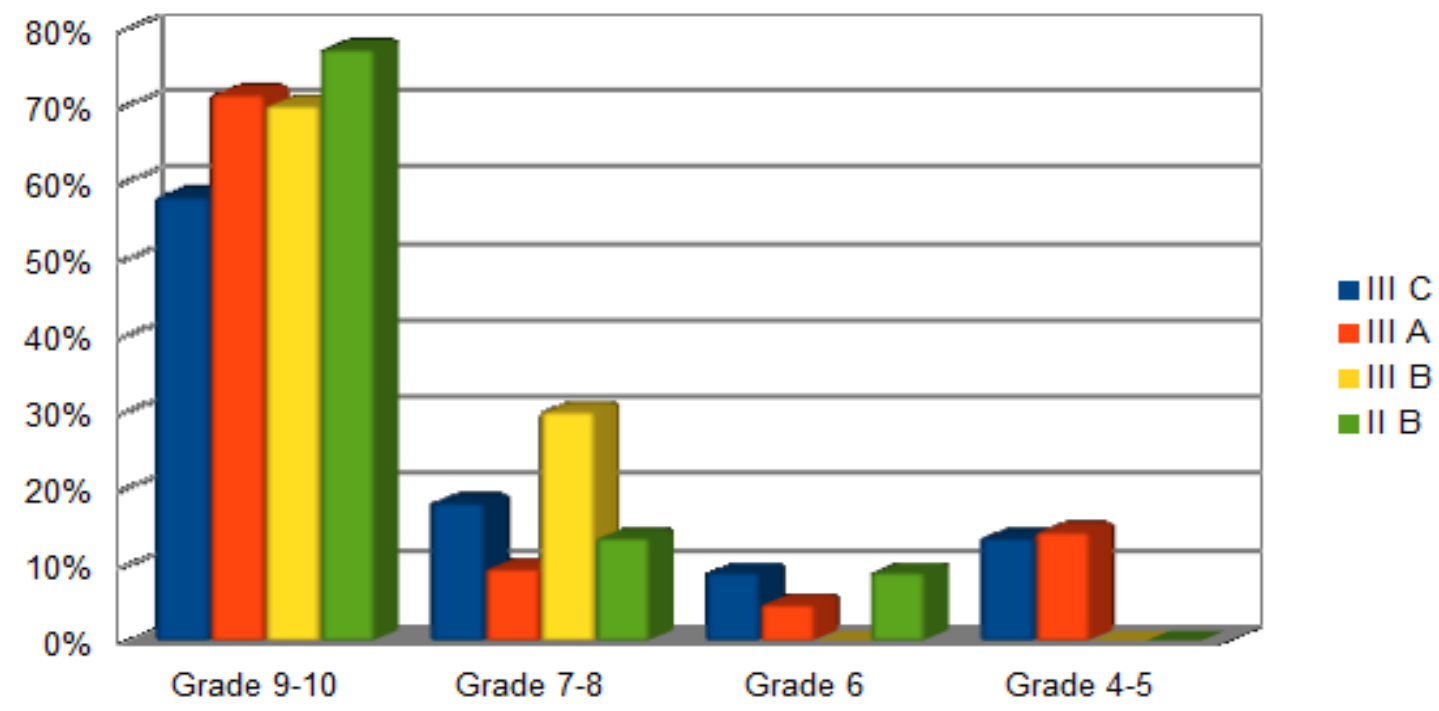

Fig. 1: Grades achieved by the four classes, grouped by grade.

In class III C, where the traditional didactic (lectures) has been utilized, there was an average of 8.22 . In III $\mathrm{A}$, where the active learning techniques have been utilized, the average was 8.33 . In both classes (III B and II B) where lessons have been carried out through the Assessment for Learning method there was the same average: 8.95 .

For each class, the average and the standard deviation of the resulted score have been calculated. The statistical significance between the averages has been verified using the software PRIMER and applying the variance analysis followed by the Student-Newman-Keuls test. 
The result shows no evidence of statistically significant differences (for $p<0.05$ ) between the four experimental groups.

\section{DISCUSSION AND CONCLUSIONS}

The investigation of the didactic makes it clear that the school shows a delay in the introduction of new topics of great importance for education and formation, such as human activities sustainability in particular related to problems with the production and consumption of food.

The results clearly show that less than half of the teachers interviewed (37.5\%) are currently focusing on the sustainable food topic dedicating to it no more than one or two hours during the whole school year. This result, if on one hand proves the originality of this didactic proposal, on the other hand represents a disheartening fact from the environmental education point of view. In fact, it is really important to form an ecological conscience in children in particular, such as those who are attending secondary schools (KS3), so that they can become valuable elements of the community, respecting the environment and its natural resources.

A quite concrete hope for the future is the data obtained from the interview on the didactic in secondary schools (KS3), referring to the two types of teachers. In fact, the trainee teachers' group (TFA) shows an undoubtedly greater interest in the topic than the teachers' group. This shows an opening toward a particular kind of reality, not related to habits or to textbooks, as an example to those teachers who said they didn't want to teach the sustainable food topic because it was not included in textbooks.

Regarding teaching methodologies, most of the teachers utilize (or would utilize) lectures instead of methods which actively involve the students, putting them at the center of the learning process. This choice seems again related more to habits than to a real conviction that the classical didactic is the best instrument. In fact, all the teachers said they are interested in experimenting new methods that could be more effective.

A great obstacle to this experimentation is time, as almost all the interviewees stated. In the secondary school (KS3) the curriculum allows just a few hours to activities which are not in the Italian Guidelines for the Curriculum, even less if these involve year 9 , because most of the time is utilized in preparation for the final examinations. In any case, the results obtained with this didactical proposal show that time is not so limiting. In fact, it was possible to realize lessons based on a non-traditional approach (AfL and active learning didactic) utilizing the same number of hours dedicated to lectures in the control group. In the analysis of the quality of the results it is to be noticed that it was not possible to use the whole potentiality of the Assessment for Learning because of the difficulty to obtain lesson hours in the two schools.

Regarding the results, the three methodologies used do not differ significantly for the grade average obtained in the final test. It is true that the abundance of the different experimental groups it is not so significant to obtain $100 \%$ reliable data.

In any case, an important result is that with the Assessment for Learning not even one student (III B and II B) has failed the test, on the contrary of what happened both in the control group (where a traditional didactic has been utilized) and in the class where the active learning didactic has been used. Furthermore, in class III $B$ the lower grade was 7 . Also the excellence percentage (grades 9 and 10) is certainly higher than the one in the control group.

Considering the distribution of the grades in the classes, it has to be noticed that with active techniques and lectures the interval of grades is wider (from 4 to 10); there is therefore a disparity in the students' knowledge: some of them have understood very well the topic whereas others don't even remember the basics. This has happened mostly with the active learning techniques, the percentage of students in the band 9-10 is in fact high but at the same time it was the class with the highest number of students who failed the test. With the Assessment for Learning method, also those who usually have poor grades managed to reach the level of the strongest peers.

In the World and European scene, many studies analyzed what are the most significant approaches to improve the learning capacity (Gaiotto et al., 2013, 2020; Tonon et al., 2013, 2020; Pavan and Santovito, 2014; Zandonella Necca et al., 2014; Toninato and Santovito, 2015; Trevisan and Santovito, 2015; Gaiotto and Santovito, 2016; Rossi and Santovito, 2016; Capparotto et al., 2017; Favaron et al., 2017; Lago et al., 2017; Meneghetti et al., 2017; Barbacovi et al., 2018; Fassinato et al., 2018; Forlin et al., 2018; Grando et al., 2018a, 2018b; Tura et al., 2018; Chiesa et al., 2019; Gallina et al., 2019; Lui et al., 2019; Palmieri et al., 2019; Bortolami et a., 2020; Corbolino et al., 2020; Fabris et al., 2020; Zanata and Santovito, 2020). Nevertheless, these practices were found not to be used in Italian schools. The results presented here show that the Assessment for Learning is of greater efficacy compared to the other methodologies. 
Another very important result is that with the Assessment for learning method the students have not learnt concepts by heart, but they understood them through reasoning.

Through questions, observation and reflection students were able to understand how strongly the topic relates to their daily lives ("so when we go to the supermarket how can we recognize local and seasonal fruits and vegetables?"). Furthermore, this has allowed them to widen their knowledge of the topic associating it to what they already knew ("To make the pasta we need grain and water to cultivate it, but we also need energy to harvest it, transport it and cook it").

Therefore, not only is the learning more effective but it is also more flexible, not depending on data and concepts learnt by heart. This is really important for a significant and effective learning, for stable and transferable experiences in other contexts, indispensable characteristics of a curriculum that aim for the creation of a lifelong knowledge.

\section{REFERENCE LIST}

Barbacovi, V., Santovito, G. \& Irato, P. (2018) Little scientists for large discoveries: an experimental approach to survey the world with classes ii of the primary school - The observation and study of plant life. In: EDULEARN18 Proceedings, IATED, Valencia. https://doi.org/10.21125/edulearn.2018.1579

Bortolami, I., Bisaccia, P., Corrà, F., Bonato, M., Irato, P. \& Santovito, G. (2020) The blue gold: an empirical research to introduce the discussion of water issue in relation to plants, animals and human in primary school. In: EDULEARN20 Proceedings, IATED, Valencia, https://doi.org/10.21125/edulearn.2020.0496.

Capparotto, A., Bramuzzo, S., Callegaro, E., Poloni, E., Corrà, F. \& Santovito G. (2017) The didactics of biology in primary school: an innovative approach to skeletal system teaching in fifth class based on comparative vertebrate anatomy. In: INTED2017 Proceedings, IATED, Valencia. http://doi.org/10.21125/inted.2017.0935

Chiesa, E., Irato, P. \& Santovito, G. (2019) The circulatory system of vertebrates and invertebrates: an empirical research to introduce in the fourth class the treatment of animal morphology in a comparative key. In: INTED2019 Proceedings, IATED, Valencia. https://doi.org/10.21125/inted.2019.0391

Corbolino, N., Bisaccia, P., Corrà, F., Bonato, M., Irato, P. \& Santovito, G. (2020) The vegetable garden. an instrument for sustainable development education and care pedagogy. In: INTED2020 Proceedings, IATED, Valencia, https://doi.org/10.21125/inted.2020.1282.

Fabris, G., Bisaccia, P., Corrà, F., Bonato, M., Irato, P. \& Santovito, G. (2020) Discovering the nervous system. An innovative teaching approach for primary school. In: EDULEARN20 Proceedings, IATED, Valencia, https://doi.org/10.21125/edulearn.2020.0889.

Fassinato, C., Nicorelli, E., Corrà, F., Irato, P., Guidolin, L. \& Santovito G. (2018) An innovative approach to deal with biodiversity at school with its investigation in different environments. In: EDULEARN18 Proceedings, IATED, Valencia. https://doi.org/10.21125/edulearn.2018.0717

Favaron, A., Ancona, E., Bramuzzo, S., Callegaro, E., Guidolin, L., Irato, P. \& Santovito, G. (2017) An innovative teaching approach to circulatory and skeletal systems based on comparative vertebrate anatomy and physiology. In: EDULEARN17 Proceedings, IATED, Valencia. http://doi.org/10.21125/edulearn.2017.1015

Food and Agriculture Organization of the United Nations (2006). Livestock's long shadow. Environmental issues and options. Publishing Policy and Support Branch, Offce of Knowledge Exchange, Research and Extension, Roma.

Food and Agriculture Organization of the United Nations (2010). Greenhouse gas emissions from the dairy sector. A Life Cycle Assessment. Publishing Policy and Support Branch, Offce of Knowledge Exchange, Research and Extension, Roma.

Forlin, E., Santovito, G., Guidolin, L. \& Irato, P. (2018) Citrus fruits. Course to educate to scientific curiosity. In: EDULEARN18 Proceedings, IATED, Valencia. https://doi.org/10.21125/edulearn.2018.1573

Gadsby, C. (2012). Perfect Assessment for Learning. Crown House Publishing, Bancyfelin. 
Gaiotto, A., Tonon, S. \& Santovito, G. (2013) The scientific method in the teaching of life sciences in primary school, The plants and their seasonal changes". In EDULEARN13 Proceedings, pp. 4226-4235.

Gaiotto A., Santovito G. (2016) An innovative didactic approach to the study of invertebrate animals in primary school. In: EDULEARN16 Proceedings, IATED, Valencia. http://doi.org/10.21125/edulearn.2016.1284

Gaiotto, A., Bisaccia, P., Bonato, M., Irato, P., Corrà, F., Santovito, G. (2020) The plants and their seasonal changes: teaching biology in primary school using the scientific method. In: INTCESS2020 Proceedings, OCERINT, Istanbul, pp 261-270.

Gallina, S., Irato, P. \& Santovito, G. (2019) Inquiry into animal tracks: an experimental application of IBSE inquiry based science education- approach in the ecological field in primary school. In: INTED2019 Proceedings, IATED, Valencia. https://doi.org/10.21125/inted.2019.0089

Ginnis, P. (2001). Teacher's Toolkit. Crown House Publishing, Bancyfelin.

Grando, G., Bramuzzo, S., Irato, P., Guidolin, L., Ferrari, L. \& Santovito, G. (2018) Introduction to the world of insects: a didactic research in kindergarten. In: INTED2018 Proceedings, IATED, Valencia. https://doi.org/10.21125/inted.2018.1066

Grando, G, Bramuzzo, S., Callegaro, E., Guidolin, L., Irato, P. \& Santovito, G. (2018) Who is afraid of insects? A didactic research in the biological field in kindergarten. In: EDULEARN18 Proceedings, IATED, Valencia. https://doi.org/10.21125/edulearn.2018.0724

Lago, A., Masiero, S., Bramuzzo, S., Callegaro, E., Poloni, E., Corrà, F. \& Santovito G. (2017) Exploring microbiology and biotechnologies: a laboratory approach to the study of yeasts and bacteria in primary school. In: INTED2017 Proceedings, IATED, Valencia. http://doi.org/10.21125/inted.2017.0992

Lui, F., Irato, P. \& Santovito, G. (2019) Discovering living organisms: a didactic research to introduce biology in kindergarten. In: EDULEARN19 Proceedings, IATED, Valencia. https://doi.org/10.21125/edulearn.2019.1040

Meneghetti, G, Bramuzzo, S., Callegaro, E., Guidolin, L., Irato, P. \& Santovito G. (2017) The kingdom of fungi in primary school: an educational research in biology field. In: EDULEARN17 Proceedings, IATED, Valencia. https://doi.org/10.21125/edulearn.2017.1023

Palmieri, G., Irato, P., Nicolosi, P. \& Santovito, G. (2019) A day at the museum. Laboratory teaching in the Museum of Zoology at the University of Padua for primary school. In: EDULEARN19 Proceedings, IATED, Valencia. https://doi.org/10.21125/edulearn.2019.1037

Pavan, C. \& Santovito, G. (2014) The laboratory didactics in the teaching -learning processes of life sciences. an educational project on microorganisms in the alimentation in primary school. In: EDULEARN14 Proceedings, IATED, Valencia, pp 7546-7555.

Pignatti, S. \& Trezza, B. (2000). Assalto al pianeta. Bollati Boringhieri Editore, Torino.

Rifkin, J. (2011). La terza rivoluzione industriale. Mondadori Editore, Milano.

Rossi, E. \& Santovito, G. (2016) Introduction to Mendelian genetics in primary school. In EDULEARN16 Proceedings, IATED, Valencia. http://doi.org/10.21125/edulearn.2016.1274

Tessaro, F. (2011). Metodologie dell'insegnamento e tecniche per l'apprendimento attivo. Lezioni di Processi e Metodologie dell'Insegnamento, SSIS Veneto, Venezia.

Tessaro, F. (2002). Metodologia e didattica dell'insegnamento secondario, Armando Editore, Roma.

Toninato, V. \& Santovito, G. (2015) The laboratory didactics in the teaching-learning processes of life sciences. an educational project on the structure of the flower and the inflorescences phenomenon in primary school. In: EDULEARN15 Proceedings, IATED, Valencia, pp 2245-2254.

Tonon, S., Gaiotto, A. \& Santovito, G. (2013) The active teaching of life sciences in primary school: a comparative approach to the musculoskeletal system. In: EDULEARN13 Proceedings, IATED, Valencia, pp. 4289-4298.

Tonon, S., Bisaccia, P., Bonato, M., Irato, P., Corrà, F. \& Santovito, G. (2020) A comparative approach to the musculoskeletal system in primary school In: INTCESS2020 Proceedings, OCERINT, Istanbul, pp 251-260.

Trevisan, T. \& Santovito, G. (2015) Teaching evolution: a laboratory approach. In: EDULEARN15 
Proceedings, IATED, Valencia, pp 2234-2244.

Tura, N., Guidolin, L., Irato, P. \& Santovito, G. (2018) From cell to inheritance of characters: an introduction to classical genetics in primary school. In: INTED2018 Proceedings, IATED, Valencia. https://doi.org/10.21125/inted.2018.1076

Zanata, M. \& Santovito, G. (2020) The "Da Vinci" Biodiversity Park (Treviso, Italy). A didactic garden as innovative support to the teaching of science in secondary school. In: INTED2020 Proceedings, IATED, Valencia, https://doi.org/10.21125/inted.2020.1474.

Zandonella Necca, I., Tamino, G. \& Santovito, G. (2014) Sustainable food: an educational proposal, for key stage 3 in secondary schools, based on the assessment for learning method. In: EDULEARN14 Proceedings, IATED, Valencia, pp 7348-7356. 